\author{
Agnieszka Lipowska-Kuźba \\ ORCID: 0000-0003-2108-4277 \\ Szkoła Podstawowej $\mathrm{Nr} 2$ w Piastowie \\ Hanna Dłutowska-Osik \\ ORCID: 0000-0003-1060-8779 \\ Zespół Szkół w Międzyborowie
}

\title{
Metody aktywizujące w klasie integracyjnej
}

\section{Activating methods in an inclusion classroom}

https://doi.org/10.34739/sn.2019.19.21

Streszczenie: Metody aktywizujące stosowane w pracy nauczyciela bardzo pomagają w inkluzji społecznej dzieci (włączeniu dzieci z niepełnosprawnością do klasy). Na podstawie własnych doświadczeń i badań widać, jak dzieci (mając przystosowane metody) w naturalny sposób integrują się ze sobą. Dlatego tak ważne jest tworzenie klas integracyjnych w szkołach ogólnodostępnych, gdzie dzieci pełnosprawne dostrzegają, że są obok nich rówieśnicy bardziej niż one potrzebujący wsparcia. W ten też sposób dzieci uczą się empatii, zrozumienia. Uczą się tego też dorośli. Z kolei praca nauczyciela jest bardziej efektywna, gdy korzysta z metod twórczego myślenia. Celem niniejszej pracy była próba ustalenia zasadności tworzenia klas integracyjnych w szkołach ogólnodostępnych i pracy metodami aktywizującymi w opinii nauczycieli i rodziców jednej ze szkół w powiecie grodziskim.

Słowa kluczowe: inkluzja, metody aktywizujące, klasy integracyjne

Abstract: Activating methods used in the work of teachers significantly help the social inclusion of children (integration of children with disabilities into a classroom). Teachers' own experiences and research show that children (when equipped with adapted methods) naturally integrate with one another. This proves why inclusion classes are greatly needed in general education schools, where children without disabilities notice that some peers beside require more assistance than they do. In this way, children are taught empathy and understanding. Adults learn that, too. Teachers' work becomes more effective when they use creative thinking techniques. The aim of this paper is to find justification for the formation of inclusion classrooms in general education schools and the use of activating methods in the opinions of teachers and parents at one of the schools within Grodzisk Mazowiecki County.

Keywords: inclusion, activating methods, integration classes

„W starożytności osoby niepełnosprawne wykluczano ze społeczeństwa, niekiedy nawet je uśmiercano" [Sowa, 1996, s. 356]. Epoka średniowie- 
cza przyniosła nadzieję dla osób niepełnosprawnych dzięki nauce Kościoła (pozwoliła na zaspokojenie potrzeb biologicznych). Wiek XVIII powoli otwierał drogę do powstawania szkół dla dzieci niepełnosprawnych - głuchych i niewidomych. Kolejnym krokiem była rehabilitacja. Po II wojnie światowej zaistniało pojęcie „integracji społecznej” w ostatnich latach "wyrównywanie szans” [Sowa, 1976, s. 356]. Międzynarodowy Rok Osób Niepełnosprawnych - 1981 r. przebiegał pod hasłem: „pełne uczestnictwo i równość”. Rok 2003 także został ogłoszony rokiem osób niepełnosprawnych [Sowa, 1976, s. 356].

Pojęcie integracji można rozumieć jako prawo do edukacji bądź pracy. Celem głównym jest przygotowanie osób niepełnosprawnych do życia w społeczeństwie. Integracja to „proces łączenia w całość, a nie włączenia do całości" [Sowa, 1976, s. 356].

Integrację pełną rozumiemy jako proces uczących się dzieci ze zwykłych klas razem z dziećmi z niepełnosprawnością. Integracja pełna wymaga pomocy ze strony szkoły, rodziców i środowiska. Z kolei integracja częściowa tworzenie klas specjalnych w szkołach ogólnodostępnych tzw. „wychowywanie niepełnosprawnych dzieci $w$ grupie rówieśniczej lub $w$ bliskim z nim sąsiedztwie" [Lipkowski, 1976, s. 359]. Integracja osób z niepełnosprawnością napotyka na przeszkody m.in.:

- fizyczne - brak dostosowania budynków do indywidualnych potrzeb;

- edukacyjne - brak specjalistycznej kadry:

- społeczne - negatywne postawy społeczeństwa w stosunku do uczniów z niepełnosprawnością [Sowa, 1976, s. 359].

Czynniki podnoszące efektywność integracji według C. Kosakowskiego, to: „właściwe rozwiązywanie legislacyjne, odpowiednie warunki bazowo-materialne, zatrudnianie właściwych specjalistów wspomagających proces kształcenia dzieci niepełnosprawnych, stworzenie odpowiednich warunków dydaktyczno-wychowawczych, przygotowanie merytoryczne i metodyczne nauczyciela - wychowawcy pod kątem potrzeb dziecka niepełnosprawnego, współpracę szkoły i nauczyciela z właściwymi specjalistami, partnerską współpracę domu rodzinnego i szkoły na rzecz wspomagania rozwoju dziecka, oddziaływanie szkoły na środowisko lokalne w celu zmiany stereotypów dotyczących niepełnosprawności" [Kosakowski, 2001, s. 359]. Gospodarka jest czynnikiem niezbędnym do przedsięwzięcia utrzymania szkół integracyjnych. Osoba niepełnosprawna wykształcona, zrehabilitowana ma możliwość uczestnictwa w społeczeństwie. Pedagodzy i specjaliści wobec procesu edukacyjnego zaczęli używać obok terminu integracja definicji inkluzja (włq̨czenie).

Inkluzja - „termin jest używany jako synonim kształcenia integracyjnego. Pojęcie to wyrosło z krytycznej analizy praktyki kształcenia integracyjnego 
w Stanach Zjednoczonych, a częściowo także w Wielkiej Brytanii. Jak podkreślają jego zwolennicy, wspólnie nauczanie zdrowych i niepełnosprawnych w USA w latach 70 i 80 XX w. koncentrowało się na aspekcie instytucjonalnym. Dla ucznia niepełnosprawnego najlepszą sytuacją jest uczęszczanie do szkoły ogólnodostępnej „włączony do wspólnoty i uznany za jej pełnowartościowego członka" [Szumski, 2006]. Zdaniem L. Visile polityka szkolnictwa w krajach zachodnich wyodrębnia dwa problemy wspólnej edukacji. Są tworzące wymagający program kształcenia specjalnego oraz takie, które stawiają na zróżnicowanie indywidualności potrzeb, umiejętności, możliwości dziecka. G. Dryżałowska wyróżnia 3 sposoby podziału systemu kształcenia: włączający system edukacji, integracja edukacyjna, nauczanie we wspólnym nurcie [Visile, 1995, za Szumski, 2006].

Tabela Edukacja integracyjna a edukacja włączająca [Kreuk-Lasocka, 2011]

\begin{tabular}{|l|l|}
\hline \multicolumn{1}{|c|}{ Edukacja integracyjna } & \multicolumn{1}{c|}{ Edukacja włączająca } \\
\hline - przypisanie niepełnosprawnych dzieci & - życie i nauka wszystkich dzieci w po- \\
szkole powszechnej & wszechnej szkole \\
- zróżnicowana pomoc dla dziecka w za- & - wsparcie dla wszystkich w rozumieniu \\
leżności od specyfiki jego trudności, kon- & systemowym \\
centracja na osobie niepełnosprawnej & \\
- dwie koncepcje teoretyczne (niepełno- & - koncepcja jednej różnorodnej grupy \\
sprawni i sprawni) & \\
- wspieranie rozwoju dzieci o specjalnych & - wspieranie zróżnicowanej grupy przez \\
potrzebach edukacyjnych przez pedago- & pedagogów specjalnych \\
gów specjalnych & \\
- wejście pedagogiki specjalnej do peda- & - zmiana miejsc - pedagogika szkolna jako \\
gogiki szkolnej, kombinacja szkolnej i spe- & wiodąca, przy syntezie szkolnej i specjal- \\
cjalnej pedagogiki & nej pedagogiki \\
- zapotrzebowanie na pedagogikę specjal- & - zapotrzebowanie na szkolną pedagogikę \\
ną i pedagogów specjalnych & i szkolnych pedagogów \\
- administracyjne rozwiązania & - uwzględnienie społecznych, emocjonal- \\
& nych oraz związanych z procesem kształ- \\
& cenia czynników \\
- zasoby dla dzieci o specjalnych potrze- & - środki dla całego systemu, planowanie \\
bach: dodatki, pomoce, plany, programy & dostępnych zasobów \\
nauczania & \\
- kontrola przez ekspertów & - rozwiązywanie problemów zespołowo \\
\hline
\end{tabular}

Źródło: A.J. Kreuk-Lasocka „Dostrzec dziecko”, Wydawnictwo Dolnośląskiej Szkoły Wyższej, Wrocław 2011, s. 21. 
Liczba uczniów w oddziale szkoły specjalnej oraz oddziale specjalnym w szkole ogólnodostępnej jest zróżnicowana w zależności od rodzaju niepełnosprawności. Struktura organizacyjna kształcenia osób z niepełnosprawnością jest tak sama jak w przypadku osób pełnosprawnych [Baraniewicz, 2009, s. 44]. Sala klasowa jest nie tylko miejscem do uczenia, a także obszarem zachowania się uczniów. Klasa jest miejscem, w którym uczniowie poznają się, wywierają na siebie wpływ, wspierają się, to prowadzi do zmiany osobowości. Uczniowie chcą być członkami klasy, zajmować w niej pozycję atrakcyjną, pragną by w klasie panowała miła atmosfera współpracy, by byli w niej akceptowani. Jeśli zabraknie w/w cech spowoduje to przykre, emocjonalne przeżycia dla dziecka i będzie czuło się źle. Uczniowie wywierają na siebie wpływ. Rodzina, szkoła (kadra) dbają, by ten wpływ był pozytywny, co ma odbicie w efektywnym nauczaniu. Izolacja od grupy rówieśniczej jakiegokolwiek dziecka pełno, czy niepełnosprawnego spowoduje niepowodzenia dydaktyczne w nauce i wpłynie negatywne na komunikację interpersonalną w grupie. Co będzie miało skutki również w dorosłym życiu. Dlatego tak ważne jest by nauczyciele, wychowawcy, rodzice uczniów pamiętali, aby szkoła była nie tylko miejscem zdobywania wiedzy, ale i środowiskiem społecznym wpływającym na rozwój ucznia jako osoby.

Często ludzie pytają „Dlaczego pedagogika włączająca?” Kształcenie integracyjne to etap pomiędzy modelem separacyjnym, a edukacją inkluzyjną (włączającą). W wielu krajach wykazano niedostatki edukacji integracyjnej [Kreuk-Lasocka, 2011, s. 11-13]. Analiza dokumentów wykazała braki, więc zaczęto realizować model kształcenia włączającego. „Model inkluzyjny zakłada nie tylko zmianę zasad finansowania i organizacji warunków kształcenia, ale przeniesienie punktów ciężkości. O ile w podejściu integracyjnym kładzie się nacisk na budowanie indywidualnych programów nauczania dla uczniów niepełnosprawnych, to $w$ kształceniu inkluzyjnym rozwija się strategię całościowego kształcenia dzieci w zbiorowości, jaką jest klasa" [Kreuk-Lasocka, 2011, s. 13]. W 2001 r. w Polsce wprowadzono zawód „asystent osoby niepełnoprawnej" - jego zadaniem jest pomoc dziecku z niepełnosprawnością, często być jego "cieniem". Dzięki pomocy asystenta i pomocy psychologiczno-pedagogicznej, którą objęte jest każde dziecko w placówce za zgodą rodzica nauczyciel nie jest osamotniony w pracy.

Celem artykułu jest przedstawienie krótkiego zarysu pracy w klasie integracyjnej metodami aktywizującymi, w szkole ogólnodostępnej w okresie wczesnoszkolnym na terenie powiatu grodziskiego. Badaniami objęto 15 nau- 
czycieli (wychowawców), 5 nauczycieli wspomagających uczących w klasach integracyjnych i 35 rodziców.

\section{Ankiety dla nauczycieli:}

[http://www.oeiizk.edu.pl/wczesno/lopuszynska/ank.pdf

http://www.ankietka.pl/ankieta/61738/metody-aktywizujące.html]

\section{Placówka z odziałem integracyjnym \\ Praca w klasach integracyjnych powszechnej szkoły podstawowej}

Wypowiedzi badanych nauczycieli pokazują, że stworzone oddziały integracyjne w szkołach dają szansę wszystkim dzieciom, uczą się wzajemnie od siebie, współpracy, tolerancji, pomocy, radości z osiągnięć innych. Dzieci uczą się akceptacji inności, starają się zrozumieć świat rówieśników z niepełnosprawnością, często też bardzo im współczują, rozśmieszają. Często małe dzieci na miarę swoich możliwości wspierają swoich nauczycieli, wychowawców, bo to oni wraz z rodzicami od pierwszego dnia szkoły uczą jak akceptować drugą osobę, stwarzają wspaniałą atmosferę jedności w klasie. Wychowawcy, nauczyciele, specjaliści pracując z uczniem o specjalnych potrzebach edukacyjnych i obejmując go pomocą psychologiczno-pedagogiczną dają mu możliwość rozwoju. Otaczają też pomocą rodziców dzieci z niepełnosprawnością, którzy wiedzą, że nie są sami i w razie jakichkolwiek problemów czy wątpliwości mogą liczyć na fachową pomoc. Ważnym elementem procesu edukacyjnego dziecka z niepełnosprawnością jest dostosowanie wymagań do programu nauczania, indywidualność podejścia. Stwarzanie możliwości udziału w konkursach dziecka z niepełnosprawnością, dzięki sukcesom u dziecka pojawia się uśmiech chęć do pokonywania trudności. W badanych szkołach pracują wysokiej rangi specjaliści, którzy ściśle współpracując ze sobą dają wszystkim dzieciom szansę na lepszy rozwój i funkcjonowanie w społeczności szkolnej oraz w życiu rodzinnym.

1. Społeczeństwo (rówieśnicy w szkole ich stosunek do dzieci ze specjalnymi potrzebami edukacyjnymi

Według wypowiedzi nauczycieli uczniowie są tolerancyjni. Zdarzają się rodzice, którzy wykazują trudność w akceptacji „inności”.

2. Zadania szkoły, by integracja nie kończyła się w klasie Zdaniem nauczycieli, aby integracja była pełna, należy pokazywać dwie strony wpływu wynikające z integracji. Cieszyć się z innymi, prowadzić pogadanki, 
rozmowy na temat ucznia z niepełnosprawnością wśród nauczycieli i rodziców. Wszystko po to, by niwelować strach rodziców i uczniów, zwłaszcza na początku poznawania klasy, w której będą przebywać wspólnie z dziećmi z niepełnosprawnością. Każda niewiedza powoduje lęk, dlatego należy go eliminować.

\section{Stosowanie metod aktywizujqcych w pracy}

Metody aktywizujące, to działania wyzwalające aktywność twórczą, pobudzające każdego członka grupy do aktywności, utrwalające sposoby zdobywania wiedzy. Według J. Krzyżewskiej „metody aktywizujące, to grupa metod nauczania, w której podmiot nauczający jest mniej aktywny od podmiotu uczącego się" [Krzyżewska, 1998, s. 10]. Zdaniem M. Taraszkiewicz każda metoda może być realizowana jako aktywizująca. Wszystko zależy od zachowania nauczyciela, który może wyzwalać określone reakcje ucznia. [Taraszkiewicz, 2000, s. 83] Stosowanie w nauczaniu strategii aktywizującej oznacza odwołanie się do uczenia na podstawie doświadczeń własnych ucznia. Według J. Jeziorskiej nauczanie aktywizujące zwane również nauczaniem poszukującym, problemowym, badawczym, polega na konkretnym działaniu ucznia. Nauczyciel ukierunkowuje, pobudza, wspiera uczniów wich rozwoju [Jeziorska, 1996, s. 91]. Większość nauczycieli prowadzi lekcje metodami aktywizującymi, wdrażają programy np.: „Spój inaczej” - które uczą m.in. przezwyciężania trudności czy lepszego przyswajania wiedzy. „Pomóż dzieciom zrozumieć świat Programy dla uczniów edukacji wczesnoszkolnej oraz uczniów z niepełnosprawnością intelektualnych" R. Naprawa, A. Tanajewska, E. Korzeniewska.

4. Metody aktywizujqce - czy sq rozwijajqce?

Wszyscy badani (nauczyciele, asystenci nauczyciela, terapeuci, wychowawcy) zgodnie twierdzą, że praca metodami aktywizującymi jest efektywna. Pozwalają na usystematyzowanie wiedzy, utrwalenie, przerwy śródlekcyjne oraz dają uczniom dużo radości.

\section{Najczęściej stosowane metody aktywizujq̨ce}

Najczęściej stosowane metody aktywizujące przez nauczycieli według A. Dziedzica, to: Burza mózgów - polega na wytworzeniu jak największej liczby pomysłów mających na celu rozwiązywanie jakiegoś problemu.

Drama - wdraża do samodzielności myślenia i działania, aktywności i otwartości, rozwija emocje, wyobraźnię i fantazję, wyrabia umiejętność współpracy w grupie. Drama rozwija i wzbogaca słownictwo młodzieży, rozwija osobowość dziecka, uczy improwizacji, logicznego myślenia. [Dziedzic, 1998, s. 21]. „Rybi szkielet - to technika którą można stosować na różne sposoby. 
Wcześniej - do rozwiązywania problemów, teraz do ewaluacji. Promyczkowe uszeregowanie - jest techniką często stosowaną w edukacji wczesnoszkolnej. Ze względu na układanie priorytetów w promyczki często nazywana jest słonecznym promyczkiem. Piramida priorytetów, kula śniegowa, drzewo decyzyjne, itp." [Krzyżewska, 1998, s. 100].

6. Co dajq metody aktywizujqce w pracy nauczyciela? „Efektywny nauczyciel posiada bogaty repertuar różnorodnych metod i technik nauczania. Aktywizowanie uczniów przybiera różne formy, najbardziej znane to nauczanie problemowe, bądź rozwiązywanie problemów pod kierunkiem nauczyciela. Najbardziej aktywizuje uczniów odkrywanie, czyli prowadzenie przez nich doświadczeń. Metody aktywizujące uczą spostrzegania, obserwowania, kojarzenia pojęć oraz logicznego myślenia [Krzyżewska, 1998, s. 102]. Ankietowani twierdzili, że stosowane metody pozwalają nie tylko na aktywność umysłową, ale i fizyczną uczniów. Jest to dobre w przypadku dzieci z nadpobudliwością psychoruchową, kiedy to w „legalny” sposób można przemieszczać się po sali w trakcie trwania zajęć, np. układać promyczki, itp.

7. Jakim człowiekiem powinien być nauczyciel w klasie integracyjnej? Zdaniem grupy badawczej nauczyciel, pracując metodami aktywizującymi, pozwala wypowiedzieć się wszystkim, poznaje każe dziecko. Uczeń może wypowiadać się, wchodząc w role (mówi i robi), wpływa na budowanie pozytywnych relacji w grupie. Dziecko, uczniowie utrwalają pisownię, wzbogacają słownictwo czynne. Dzięki efektywnej pracy wychowawca aktywizuje uczniów zarówno zdolnych, jak i mających trudności w nauce, umacnia grupę, co za tym idzie osiąga dobre wyniki nauczania. Nauczyciel angażuje wszystkich uczniów do pracy.

\section{Ankieta dla rodziców uczniów, których dzieci uczęszczają do klasy integracyjnej: \\ [http://www.oeiizk.edu.pl/wczesno/lopuszynska/ank.pdf; http://www.ankietka.pl/ankieta/61738/metody-aktywizujące.html]}

1. Dobre strony uczęszczania dziecka do klasy integracyjnej Według przebadanych rodziców dzieci już w młodszym wieku szkolnym uczą się akceptacji inności, stykają się z agresją, lekceważeniem nauki. Widzą pozytywne i negatywne strony uczęszczania dziecka do oddziału integracyjnego.

2. Samopoczucie rodziców dziecka uczęszczajq̨cego do klasy integracyjnej po roku 
Pozytywnie, rozumie człowieka z niepełnosprawnością. Oprócz poznanego materiału, uczą się pokonywania trudności. Rodzice jak najbardziej są zadowoleni z wyboru.

3. Jak czuje się dziecko w klasie integracyjnej?

Rodzice pisali, że ich dziecko czuje się dobrze, dość dobrze w klasie. Jest to zasługą wychowawcy, asystenta nauczyciela i ogólnie kadry w szkole, atmosfery pozytywnej panującej w szkole. „W. Dykcik wymienia szereg dodatkowych zasad, których stosowanie jest niezbędne $\mathrm{w}$ indywidualnej pracy $z$ uczniem o specjalnych potrzebach edukacyjnych: zasada sukcesu - uwzględnianie aktualnych potrzeb i możliwości dziecka; - zasada ścisłej integracji doświadczeń percepcyjnych, ruchowych i językowych w ćwiczeniu różnych funkcji praktycznych; - zasada aktywnego, wielostronnego mobilizowania do wykonywania zadań przez stosowanie różnorodnych form ćwiczeń; - zasada doboru odpowiednich metod, technik i środków; -zasada wyzwolenia otwartości, komunikowaniu się w najbliższym otoczeniu; -zasada pełnej akceptacji i tolerancji, zasada stopniowego, ewolucyjnego i regularnego osiągania zamierzonych celów pracy oraz jej kontynuacji w perspektywie całej edukacji - zasada uczenia się życia w środowisku przez uczestnictwo, działanie i przeżywanie oraz dopasowanie wymagań do poziomu rozwoju i jego następnych etapów, całościowego, kompleksowego, wszechstronnego, zintegrowanego podejścia do dziecka niepełnosprawnego [Paszkiewicz, 1998, s. 17, 18]. Zadaniem nauczyciela jest nie dopuścić do wykluczenia dziecka o specjalnych potrzebach edukacyjnych z toku zajęć, należy stworzyć odpowiednie warunki dopasowane do potrzeb dziecka, np.: tablica multimedialna, środki wizualne dopasowane do możliwości dziecka, wydłużenie czasu pracy, dzielenie materiału na mniejsze partie, różnorodność form pracy. Umożliwienie uczniowi ze specjalnymi potrzebami edukacyjnymi korzystania z nauki języków obcych na miarę jego potrzeb i możliwości, stosowanie kart zadań do samodzielnego rozwiązywania o różnym stopniu trudności, jasne wyznaczenie granic oraz reguł obowiązujących w klasie [MEN, 2010, s. 11-12].

4. Czy nauka w klasie integracyjnej będzie miała wpływ na Państwa dziecko $w$ dorosłym życiu?

Według ankietowanych rodziców uczęszczanie dziecka do klasy integracyjnej będzie miało pozytywny wpływ na jego podejście do inności, naturalnym stanie się chęć pomocy słabszym. Dzieci zetknąwszy się z problemami niepełnosprawności będą tolerancyjne. We wszystkich naszych działaniach myślą przewodnią powinny być słowa Marii Grzegorzewskiej: „Nie ma kaleki, jest dziecko". 


\section{Podsumowanie}

Zarys badań pokazał, jakim człowiekiem powinien być nauczyciel w klasie integracyjnej. Jak pracować z uczniami w oddziale integracyjnym, jak poznawać dziecko. Pamiętajmy, że co zaszczepimy u dziecku w pierwszym etapie kształcenia znajdzie swój wyraz w kolejnych oraz dorosłym życiu. Co nauczyciel wypracuje z dzieckiem w wieku szkolnym, to zapada głęboko we wnętrzu fizycznej i duchowej natury człowieka. Współczesne szkoły można nawiązać do istoty pedagogiki waldorfowskiej, którą jest skupienie uwagi i zainteresowania na dzieciach.

Nauczyciele pracujący w klasach integracyjnych powinni sami akceptować dziecko z niepełnosprawnością. Niezbędne jest przestrzeganie pewnych ogólnych postulatów:

- praca dydaktyczno-wychowawcza powinna być dokładnie przemyślana i zaplanowana;

- dobór zadań od bardziej ciekawych, uwzględniających zainteresowanie dziecka;

- wskazówki i pouczenia winny mieć charakter pozytywny i konkretny, np. „włóż kurtkę, a nie „ubierz się", nie zawierać sformułowań: to dla ciebie jest za trudne, nie poradzisz sobie z tym zadaniem;

- stosowanie wzmocnień pozytywnych jest skuteczniejsze niż narzekanie, podobnie jak u dzieci zdrowych, częste podkreślanie zachowań poprawnych;

- uwzględniać tempo myślenia i wykonania;

- we wszystkich -nawet najtrudniejszych -sytuacjach zachować spokój.

\section{Scenariusze zajęć terapeutycznych z zastosowaniem metod aktywizujących}

\section{J. Krzyżewskiej}

Scenariusz 1. Blok tematyczny: Pisownia z „rz", „̇̈".

Temat zajęć: Utrwalenie wiadomości z pisownią rz, ż.

Cele: uczeń aktywnie uczestniczy w zajęciach, uczeń zna reguły pisowni z "rz”, potrafi zapisać i narysować wyraz z "rz".

Środki dydaktyczne: obrazki do zajęć przygotowane przez nauczyciela, karty pracy z książki z ortografii przygotowane do możliwości ucznia (stopniowanie trudności).

Metody pracy: pogadanka, promyczkowe uszeregowanie, burza mózgów. 
Przebieg zajęć:

1. Rymowanki - po jakich spółgłoskach piszemy „rz"

P - Prosiła B - Babka T - Tadka D - Daj K - Kawałek G - Gnatka W - Wołała J - Jeszcze Ch - Chrzan [APN, 2014, s. 133].

2. Krzyżówka z „rz” (przy dzieciach ze specjalnymi potrzebami edukacyjnymi powinny być wyrazy do wpisania do krzyżówki, a nie tylko sam rysunek.

3. Podanie definicji $z$ „rz". „Rz” piszemy, gdy wymienia się na „ $r$ ”.

Rowerzysta (obok rysunek chłopca na rowerze)

Rower (obok rysunek roweru) [Baścik-Kołek, 2015, s. 39].

4. Metoda promyczkowe uszeregowanie:

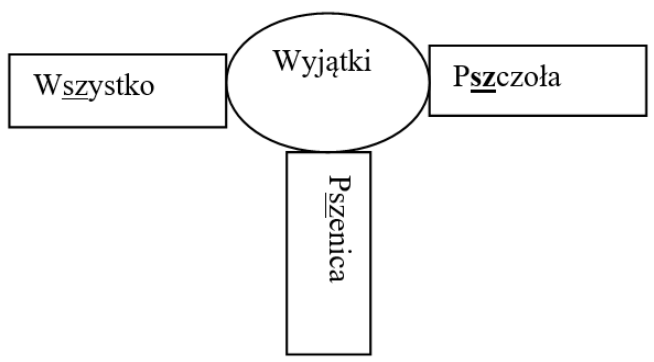

5. Ćwiczenie 1, s. 40

Orzeł - orły (Obok namalowane obrazki liczba pojedyncza, liczba mnoga)

6. Podsumowanie zajęć metodą „Burzy mózgów”- Wymień wyrazy z „rz" lub narysuj.

\section{Scenariusz 2. Blok tematyczny: Szukamy „ó” w wyrazach.}

Czas: 45 minut.

Temat: Utrwalenie pisowni wyrazów z "ó" wymiennym i niewymiennym Cele: ćwiczenia w czytaniu i pisaniu, uczeń zna pisownię „ó", czyta tekst głośno ze zrozumieniem, potrafi pracować $w$ grupie.

Metody: rozmowa, pokaz, słowna - skojarzenia, aktywne działanie.

Formy: praca indywidualna, praca zbiorowa, praca w grupach.

Przebieg zajęć:

1. Rozwiązywanie krzyżówki z wyrazami z „ó” (narysowane obrazki i obok napisy dla dzieci z trudnościami). (wróbel, choinka, buty, góral, miód).

2. Rebus z wyrazami z „ó": lodów, chłopców, panów... (praca w zeszycie). 
3. Ćwiczenia z ortografii z literą „ó”. (Szukanie wyrazów z „ó”, rozwiązywanie zagadek z literą „ó").

4. Przerwa śródlekcyjna - śpiewanie poznanej piosenki.

5. Karty pracy z literą „ó" - podpisywanie odpowiednich obrazków, kolorowanie wyrazów z „u”, „ó": róża, król, góra, piórko, ołówek.

6. Metoda J. Krzyżewskiej „Promyczkowe uszeregowanie” - uczniowie piszą wyrazy z literą „ó" (jako utrwalanie pisowni).

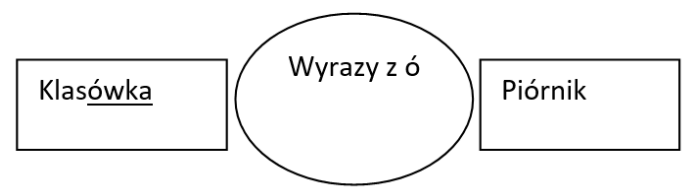

7. Balony - na podsumowanie zajęć praca w grupach - hasła w balonach (rebus wróbel, jaskółka wpisanie odpowiedniej litery w wyrazie).

8. Metoda graffiti na podsumowanie zajęć - nauczyciel dzieli dzieci na grupy: Każda grupa otrzymuje plakat z zadaniem: I grupa - Czego dziś nauczyliśmy się na zajęciach...; II grupa - co chcielibyśmy zmienić podczas zajęć...; III grupa - Pani zapewniła nam..., IV grupa - Nie chciałbym, aby...

\section{Scenariusz 3. Blok tematyczny: Spotkanie z bohaterami „Plastusiowego pamiętnika"}

Temat: „Plastusiowy pamiętnik"

Cele: uczeń zna treść lektury;uczeń układa i zapisuje zdanie z rozsypanki wyrazowej, określa liczbę liter, głosek i sylab w wyrazie, uczeń wskazuje właściwe źródło informacji, wypowiada się pełnymi zdaniami.

Metody: pokaz, rozmowa, opis, objaśnienia, metody aktywizujące J. Krzyżewskiej

Formy: zbiorowa, indywidualna

Materiały dydaktyczne: pomoce przygotowane przez nauczyciela: kartony, krzyżówka, ilustracje do lektury

Przebieg zajęć:

1. Czytanie fragmentu lektury przez nauczyciela „Dlaczego nazywam się Plastuś?” [Nosowska, 2013, s. 118]. Pogadanka na temat w/w.

2. Metoda „graffiti”: Grupa I otrzymuje plakat z zadaniem „Podkreśl właściwą odpowiedź o Plastusiu, Gr. II Kto stworzył Plastusia?... Gr. III Gdzie mieszka Plastuś?... Gr. IV Dlaczego mam na imię Plastuś?" [Nosowska, 2013, s. 118] (Na każdym rysunku grupa po napisaniu odpowiedzi rysuje ją). 
3. Metoda „piramida priorytetów” - dzieci układają piramidę z małych kartonów (prostokątów). Zadanie: Opowiedz, jak wygląda Plastuś?

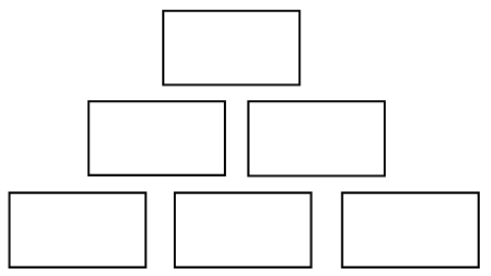

4. Metoda promyczkowe uszeregowanie: „Który z tych piórników należy do Tosi? Pokoloruj go!" [Nosowska, 2013, s. 118] (Rysunki trzech piórników).

a) „Narysuj swój piórnik” [Nosowska, 2013, s. 119]

b) „Z czego jest wykonany Twój piórnik? Do czego służył piórnik Tosi? Do czego służą przybory szkolne?" [Nosowska, 2013, s. 119]

\section{Prawda czy fałsz.}

„Plastuś należy do przyborów szkolnych”, Tosia kupiła Plastusia w sklepie z zabawkami, Plastuś jest maskotką, Plastuś mieszka z przyborami szkolnymi, ale do nich nie należy" [Nosowska, 2013, s. 121]

6. Czytanie treści - O pamiętniku w czerwonym zeszyciku.

Metoda „Kosz i walizeczka " Kosz uczniowie piszą negatywne emocje, walizeczka: pozytywne emocje.

6. Krzyżówka „Wymazuje, co ołówek napisał; Ludzik ulepiony przez Tosię; Kolega Pankracka; Mieszkańcy piórnika Tosi; Który często łamie nos; Przewiązała zeszyt". [Nosowska, 2013, s. 128] (I do każdego zdania jest przygotowana ilustracja).

7. Nauczyciel czyta fragment „O moim biednym nosie i o szkaradnej Zosi”.

8. Z ilu liter składa się wyraz „Plastuś”? A ile jest w nim głosek? Z ilu sylab składa się to słowo?

9. Zadania tekstowe:

Tosia dostała od Rodziców piórnik. W piórniku były 4 przybory szkolne, Tosia na zajęciach plastycznych wyjęła z piórnika gumkę. lle przyborów zostało w piórniku? Analiza zadnia: O czym jest zadnie?, Co wiemy o zadaniu?, O co nas pytają? Jak zapiszemy odp.? (ilustracje do zadania przygotowane przez nauczyciela bądź użycie tablicy multimedialnej). 
10. Lepienie Plastusia z plasteliny.

11. Tosia zaobserwowała na dachu stado szpaków złożone z 10 ptaków. Na drucie spostrzegała 4 jaskółki, a nad łąką - słowika. Ile ptaków zaobserwowała Tosia? (Ilustracje do zadnia) [Pastuła, 2014, s. 9]. Analiza zadania.

12. Podsumowanie zajęć; metoda: burza mózgów, Co wiesz o postaci Plastusia?

\section{Literatura}

Baraniewicz D., (2009), Uwarunkowania akceptacji ucznia w klasie integracyjne, Uniwersytet Pedagogiczny, Kraków.

Baścik-Kołek D., (2015), Mała ortografia, Wydawnictwo JUKA (klasa II), Kielce. Dziedzic A., W.E. Kozłowska, (1998), Drama na lekcjach historii, WSIP, Warszawa.

hppt://www.ankietka.pl/ankieta/61738/metody-aktywizujące.html http://boberkowy-world.blogspot.com/2015/04/ukad-soneczny-konspekt http://www.ankietka.pl/ankieta/61738/metody-aktywizujące.html http://www.oei., Por., Jizk.edu.pl/wczesno/lopuszynska/ank.pdf; http://www.oeiizk.edu.pl/wczesno/lopuszynska/ank.pdf;

Jeziorska J., (1996), Szkolne pytania czyli dylematy nauczania, Wydawnictwo Salezjańskie, Warszawa.

Kreuk-Lasocka A.J., (2011), Dostrzec dziecko, Wydawnictwo Dolnośląskiej Szkoły Wyższej, Wrocław.

Krzyżewska J., (1998), Aktywizujqce metody i techniki w edukacji wczesnoszkolnej, Wyd. AU OMEGA, Suwałki.

Lipkowski O., (1976), Problem integracji, „Szkoła Specjalna”, nr 1.

Nosowska D., (2013), Lektury dla klasy I, Wydawnictwo Zielona Sowa, Warszawa.

Pustuła A., (2014), Zadania do rozwiqzania klasa II, Wydawnictwo Juka, Kielce. Rosłaniec M., Szydłowska B., (2016), Gramatycy i ortografii na start klasa II, Wydawnictwo Olimp, Panowo Biskupie.

Sęk H., (2001), Wprowadzenie do psychologii klinicznej, Wydawnictwo Scholar, Warszawa.

Szumski G., (2006), Integracja kształcenia niepełnosprawnych: sens i granice zmiany edukacyjnej, Wydawnictwo Naukowe PWN, Wydawnictwo APS, Warszawa. 
Taraszkiewicz M., (2000), Jak uczyć lepiej? Czyli refleksyjny praktyk w działaniu, Wydawnictwo CODN, Warszawa.

Zacharuk T., (2011), Edukacja włq̨czajqca szansq dla wszystkich uczniów, Mazowiecki Kwartalnik Edukacyjny „Meritum”, nr 1(20). 